\title{
Comparative analysis of the life cycle impact assessment of available cement inventories in the EU Alejandro Josa ${ }^{\mathrm{a}}$, Antonio Aguado ${ }^{\mathrm{a}}$, Ewan Byars ${ }^{\mathrm{b} *}$, Arnaldo Cardim ${ }^{\mathrm{c}}$ \\ ${ }^{\mathbf{a}}$ Technical University of Catalonia (UPC), School of Civil Engineering (ETSECCPB), Jordi Girona 1-3, Módulo D2/C1, E-08034 Barcelona, Spain \\ b The University of Sheffield, Centre for Cement and Concrete, Department of Civil and Structural Engineering, Sir Frederick Mappin Building, Mappin Street, Sheffield S1 3JD, United Kingdom \\ c Polytechnic School of Penambuco University, Civil Engineering Department, Rua Benfica, 455 - Madalena, CEP 50.750-410 - Brazil
}

\begin{abstract}
Life Cycle Impact Assessment (LCIA) is one of basic steps in Life Cycle Assessment methodology (LCA). This paper presents a comparative study of the LCIA of different life cycle inventories (LCI) for EU cements. The analysis unit used is the manufacture of $1 \mathrm{~kg}$ of cement, from "cradle to gate". The impact categories considered are those resulting from the manufacture of cement and include greenhouse effects, acidification, eutrophication and summer and winter smog, amongst others.
\end{abstract}

The results of the study highlighted some inconsistencies in existing inventories. As for the LCIA, the main environmental interventions related to cement manufacture were classified and characterised and their effect on different impact categories analysed. Differences observed in evaluation of the impact of cement type were essentially related to their clinker content.

Keywords: life cycle impact assessment, life cycle assessment, life cycle inventory, cement production, system boundary, clinker

\section{Introduction}

Life cycle assessment (LCA) methodology is used to evaluate the impact of processes or products on the environment [1]. Fundamental to this analysis is the inclusion of every stage of a process or product's life cycle. In the case of products, every stage from the production of the raw materials to the end of their useful lives and their use and maintenance should be included. Thus, all significant environment impacts in their life cycle can be addressed.

In some cases, however, a full life cycle (cradle to grave) analysis is impossible and the analysis must terminate at an intermediate stage (cradle to gate) or begin and end at intermediate stages (gate to gate). This is the case, for example, if one analyses cement production which has multiple specific applications (beams, pillars, pavements, bridges, etc.) and therefore disallows a unique life cycle to be defined (cradle to gate).

This type of partial analysis (not cradle to grave) is useful for comparing and evaluating possible improvements in environmental behaviour as well as constructing more complete life cycles for specific cement endproducts (beams, columns, pavements etc).

One of the fundamental parts of a LCA is the undertaking of a life cycle inventory (LCI), in which the energy and materials used and wastes emitted during the manufacture of a product are identified and quantified (in solid, liquid or gas form). This typically yields a long list of environmental interventions that is difficult to manage and interpret [1-5].

These environmental interventions in the inventory are classified and characterised during the life cycle impact assessment (LCIA) stage. During this process the results are summarised into a short list of impact categories. These impact categories (such as the greenhouse effect or acidification), are much easier to interpret than the environmental interventions themselves.

An earlier paper [6] compiled and analysed LCI for EU cements and included both input and output data. The latter focused on main emissions resulting from the production of cement $\left(\mathrm{CO}_{2}, \mathrm{SO}_{2}, \mathrm{NO}_{\mathrm{x}}\right.$ and dust). Alternative

\footnotetext{
* Corresponding author. Tel.: 0114222 5715; Fax: 0114222 5700; E-mail address: DrByars@aol.com
} 
techniques were used to evaluate these emissions and thus compare the results from different LCI and confirm the validity of the methodology.

Key issues in available LCI were summarised in the previous paper by the authors [6], such as a) the identification of some inconsistencies in the figures included in some of them, b) the possibility of using theoretical models to estimate some environmental interventions, c) that emissions are primarily produced during the production of clinker, and d) that the types of cement that require the least amount of energy for their production are those which use greater proportions of different types of additives.

The main objective of this paper is to undertake a comparative study of the impact assessment of the same LCI analysed in [6]. The analysis unit used was $1 \mathrm{~kg}$ of Portland cement, with or without some types of additives. These LCI were obtained from references [7] and [8] and from information provided by several manufacturers and are listed in Table 1 ([9-17]. Reference [6] provides further detailed information on the source data. It should be noted that these inventories depend, among other things, on the system boundaries utilised in each case.

LCA can be undertaken by following a number of different specific methodologies [18-21] which can use different impact categories such as greenhouse effect, stratospheric ozone depletion, acidification, eutrophication or toxicity as well as have different hypotheses for evaluating their environmental impact. This paper uses the CML 1992 methodology ([18]), which is one of the most widely used and accepted in Europe and has recently been updated ([21]).

\begin{tabular}{|c|c|c|c|c|}
\hline \multirow{2}{*}{$\begin{array}{l}\text { Original cement name and reference } \\
\text { Cement Portland I [7] }\end{array}$} & \multicolumn{2}{|c|}{ Classification } & \multirow{2}{*}{\begin{tabular}{|c|} 
Clinker \\
$\mathbf{( \% )}$ \\
$95-100$
\end{tabular}} & \multirow{2}{*}{$\begin{array}{l}\text { Origin } \\
\text { Holland }\end{array}$} \\
\hline & Type I & Portland cement & & \\
\hline Cement Portland [7] & Type II /A-S & Portland slag cement & $80-94$ & Holland \\
\hline Blastfurnace slag cement [7] & Type III / B & Blastfurnace cement & $20-34$ & Holland \\
\hline Cement Hoogoven I [7] & Type III / B & Blastfurnace cement & $20-34$ & Holland \\
\hline Portland ash cement [7] & Type IV / B & Pozzolanic cement & $45-64$ & Holland \\
\hline Cement CH [7,(9)] & Type I & Portland cement & $95-100$ & Switzerland \\
\hline Cement $N[8,(10)]$ & Type I & Portland cement & $95-100$ & Sweden \\
\hline Portlandcement NL1 $[8,(11)]$ & Type I & Portland cement & $95-100$ & Holland \\
\hline Cement S $[8,12]$ & Type I & Portland cement & $95-100$ & Sweden \\
\hline Cement SF1 [8.13] & Type I & Portland cement & $95-100$ & Finland \\
\hline Cement SF2 [8.14] & Type I & Portland cement & $95-100$ & Nordic Countrie \\
\hline Portlandcement A $[8,(15)]$ & Type II / A-S & Portland slag cement & 80-94 & Austria \\
\hline Portlandcement NL2 $[8,(16)]$ & Type II / A-S & Portland slag cement & $80-94$ & Holland \\
\hline Portlandcement NL3 [8,(17)] & Type II / B-S & Portland slag cement & $65-79$ & Holland \\
\hline Blastfurnace slag cement NL1 $[8,(16)]$ & Type III / B & Blastfurnace cement & $20-34$ & Holland \\
\hline Blastfurnace slag cement NL2 [8,(17)] & Type III / B & Blastfurnace cement & $20-34$ & Holland \\
\hline
\end{tabular}

TABLE 1. LCI utilised in this paper ([6])

\section{Impact assessment}

The LCIA is also a fundamental stage in a LCA [1] and consists of a number of parts. In the first or classification part, each environmental intervention in the LCI is associated with the impact category or categories in which it has an effect (for example, $\mathrm{CO}_{2}$ is associated with the greenhouse effect).

In the second or characterisation part, the relative effects of all the environmental interventions associated with each of the different impact categories are compared with one another (for example, $1 \mathrm{~kg}$ of $\mathrm{CH}_{4}$ has the same impact on the greenhouse effect as do 11 $\mathrm{kg}$ of $\mathrm{CO}_{2}$ ). A reference unit is defined for each impact category (for example, equivalent $\mathrm{CO}_{2}$ on the greenhouse effect) as well as the corresponding characterisation factors $(11$, as indicated in the case of $\mathrm{CH}_{4}$ ). Additionally, there may be a later phase of normalisation, in which the results of each impact category are divided by a reference figure (for example, for the greenhouse effect, worldwide $\mathrm{CO}_{2}$ emissions is sometimes used). 
Of all the impact categories considered in the 1992 CML methodology ([18]), those that are affected by one or more of the main emissions resulting from the production of cement were the first to be analysed. In agreement with [6], these emissions are stipulated as $\mathrm{CO}_{2}, \mathrm{SO}_{2}, \mathrm{NO}_{\mathrm{x}}$ and dust, which in Table 2 are presented in association with the corresponding impact categories. This Table also includes the corresponding characterisation factors of these environmental interventions.

The impact categories are classified as global, regional or local, depending on their geographical area of impact. This sort of classification facilitates a subsequent analysis of the results and decision-making depending on the scope of the point of view adopted.

\begin{tabular}{|l|l|c|c|c|c|}
\hline \multirow{2}{*}{ Impact area } & \multirow{2}{*}{ Impact category } & \multicolumn{4}{|c|}{ Airborne emissions of the system } \\
\cline { 3 - 6 } & & $\mathbf{C O}_{2}$ & $\mathbf{S O}_{2}$ & $\mathbf{N O}_{\mathbf{x}}$ & Dust \\
\hline \hline Global & Greenhouse effect & 1 & & & \\
\hline \multirow{2}{*}{ Regional } & Acidification & & 1 & 0.7 & 1 \\
\hline Local & Eutrophication & & & & 1 \\
\hline
\end{tabular}

TABLE 2. Initial impact categories considered in the analysis

\section{Study of the global environmental impacts 3.1. Greenhouse effect}

Table 3 shows the results of the greenhouse effect characterisation of the different types of cement studied. The values are expressed in grams of equivalent $\mathrm{CO}_{2}$ per $\mathrm{kg}$ of cement produced.

This Table shows the relevant gas emissions related to the greenhouse effect, which, in this case, are carbon dioxide $\left(\mathrm{CO}_{2}\right)$, methane $\left(\mathrm{CH}_{4}\right)$ and nitrous oxide $\left(\mathrm{N}_{2} \mathrm{O}\right)$, which have the corresponding characterisation factors of 1,11 and 270 respectively. The individual contribution of each gas emitted are also shown as percentages in order to determine their relative influence on this impact category.

Of the values shown in the Table, one can deduce that the total influence of methane $\left(\mathrm{CH}_{4}\right)$ and nitrous oxide $\left(\mathrm{N}_{2} \mathrm{O}\right)$ on the greenhouse effect is very small in comparison to the contribution of carbon dioxide $\left(\mathrm{CO}_{2}\right)$, which lies between 98.8 and $100 \%$. This is because despite having a lower characterisation factor (1), the amount of $\mathrm{CO}_{2}$ emitted is much higher than the other gases.

It is important to acknowledge the substantial quantitative effects of $\mathrm{CO}_{2}$ emissions. Depending on the type of cement, these can reach values as high as $800 \mathrm{~g}$ of $\mathrm{CO}_{2}$ per $\mathrm{kg}$ of Type I cement. This data supports the opinion of the Intergovernmental Panel on Climatic Change [22], which suggests that the production of cement is a relevant industrial source of $\mathrm{CO}_{2}$ emissions.
The variations shown between the emission values of different cements in Table 3 are due mainly to the amount of clinker in the cements. The variations in total $\mathrm{CO}_{2}$ may be related to the type of resources utilised (mainly the fuels).

Despite the fact that Type I cements typically have a $\mathrm{CO}_{2}$ emission of $800 \mathrm{~g}$ per $\mathrm{kg}$ of cement, quoted figures can be as low as $354.70 \mathrm{~g}$ per $\mathrm{kg}$, as shown for the Cement Portland I [7]. The variation may be due to the fact that, for Cement Portland I, some of the emissions caused by the production of clinker are being omitted (perhaps only those associated with the fuel are considered), either because a certain proportion of these emissions are for some reason omitted from the inventory, or due to variations in definition of the system boundaries. This is confirmed by the fact (as is shown in [23]) that The Netherlands, the country of origin of this cement, has only one furnace producing clinker and three plants producing cement, all of which should yield very similar results (compare Cement Portland I with Portland Cement NL1 $[8,16])$.

The principal source of variation in the results for the remaining types of cements is the amount of clinker in each. The inconsistencies between some of the results have already been analysed in [6] and are due to several factors including the definition of system boundaries and numerical errors. In cement types that incorporate high percentages of pozzolanic or cementitious additions (such as blast furnace slag or fly ashes), for example, Type III cements, the $\mathrm{CO}_{2}$ emission reductions can be of the order of $60-70 \%$ compared to corresponding Type I cements. 


\begin{tabular}{|c|c|c|c|c|c|}
\hline Type & Cements & $\mathrm{CO}_{2}$ & $\mathrm{CH}_{4}$ & $\mathrm{~N}_{2} \mathrm{O}$ & Total \\
\hline \multirow{7}{*}{ I } & Cement Portland I & $\begin{array}{c}354.70 \\
(100 \%)\end{array}$ & $\begin{array}{c}0.00062 \\
(0 \%)\end{array}$ & - & $\begin{array}{l}354.70 \\
(100 \%)\end{array}$ \\
\hline & Cement $\mathrm{CH}$ & $\begin{array}{l}810.00 \\
(100 \%)\end{array}$ & - & - & $\begin{array}{l}810.00 \\
(100 \%)\end{array}$ \\
\hline & Cement N & $\begin{array}{c}813.00 \\
(99.5 \%)\end{array}$ & $\begin{array}{c}3.44 \\
(0.5 \%)\end{array}$ & $\begin{array}{c}0.60 \\
(0 \%)\end{array}$ & $\begin{array}{l}817.04 \\
(100 \%)\end{array}$ \\
\hline & Portlandcement NL1 & $\begin{array}{l}853.00 \\
(100 \%)\end{array}$ & 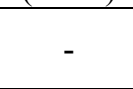 & - & $\begin{array}{l}853.00 \\
(100 \%)\end{array}$ \\
\hline & Cement S & $\begin{array}{c}805.00 \\
(99.6 \%) \\
\end{array}$ & $\begin{array}{c}3.3 \\
(0.4 \%)\end{array}$ & $\begin{array}{c}0.000039 \\
(0 \%)\end{array}$ & $\begin{array}{l}808.30 \\
(100 \%)\end{array}$ \\
\hline & Cement SF1 & $\begin{array}{c}780.00 \\
(98.9 \%)\end{array}$ & $\begin{array}{c}8.25 \\
(1.1 \%)\end{array}$ & $\begin{array}{c}0.00057 \\
(0 \%)\end{array}$ & $\begin{array}{l}788.25 \\
(100 \%)\end{array}$ \\
\hline & Cement SF2 & $\begin{array}{c}812.70 \\
(98.8 \%)\end{array}$ & $\begin{array}{c}9.93 \\
(1.2 \%)\end{array}$ & $\begin{array}{c}0.016 \\
(0 \%)\end{array}$ & $\begin{array}{l}822.65 \\
(100 \%)\end{array}$ \\
\hline \multirow{4}{*}{ II } & Cement Portland & $\begin{array}{c}918.30 \\
(99.8 \%) \\
\end{array}$ & - & $\begin{array}{c}1.84 \\
(0.2 \%)\end{array}$ & $\begin{array}{l}920.14 \\
(100 \%)\end{array}$ \\
\hline & Portlandcement A & $\begin{array}{l}586.00 \\
(100 \%)\end{array}$ & - & - & $\begin{array}{l}586.00 \\
(100 \%)\end{array}$ \\
\hline & Portlandcement NL2 & $\begin{array}{l}807.00 \\
(100 \%)\end{array}$ & - & - & $\begin{array}{l}807.00 \\
(100 \%)\end{array}$ \\
\hline & Portlandcement NL3 & $\begin{array}{l}289.00 \\
(100 \%) \\
\end{array}$ & - & - & $\begin{array}{l}289.00 \\
(100 \%)\end{array}$ \\
\hline \multirow{4}{*}{ III } & Cement Hoogoven I & $\begin{array}{l}221.70 \\
(100 \%)\end{array}$ & $\begin{array}{c}0.00069 \\
(0 \%)\end{array}$ & - & $\begin{array}{l}221.70 \\
(100 \%)\end{array}$ \\
\hline & Blast furnace slag cement & $\begin{array}{c}334.10 \\
(98.9 \%)\end{array}$ & - & $\begin{array}{c}3.85 \\
(1.1 \%)\end{array}$ & $\begin{array}{l}337.95 \\
(100 \%)\end{array}$ \\
\hline & Blastfurnace slag cement NL1 & $\begin{array}{l}212.00 \\
(100 \%)\end{array}$ & - & - & $\begin{array}{l}212.00 \\
(100 \%)\end{array}$ \\
\hline & Blastfurnace slag cement NL2 & $\begin{array}{l}134.00 \\
(100 \%)\end{array}$ & - & - & $\begin{array}{l}134.00 \\
(100 \%)\end{array}$ \\
\hline IV & Cement Portlandash & $\begin{array}{c}692.90 \\
(99.7 \%)\end{array}$ & - & $\begin{array}{c}1.82 \\
(0.3 \%)\end{array}$ & $\begin{array}{c}694.72 \\
(100 \%)\end{array}$ \\
\hline
\end{tabular}

TABLE 3. Characterisation of the cements studied with respect to the global greenhouse effect (in grams of equivalent $\mathrm{CO}_{2}$ per $\mathrm{kg}$ of cement and relative percentage)

\subsection{Other sources of global environmental impact}

As for other sources of global environmental impact (such as the contribution to the stratospheric ozone depletion), the production of cement does not have significant effects.

\section{Study of the regional environmental impact}

Some of the emissions caused by the production of cement have regional effects, such as acidification and eutrophication. As shown in Table 2, the main emissions resulting from the production of cement that contribute to these processes are sulfur dioxide $\left(\mathrm{SO}_{2}\right)$ and nitrogen oxides $\left(\mathrm{NO}_{\mathrm{x}}\right)$. However, as these are among the environmental interventions in the inventories, other influential emissions have also been included in this study, such as hydrochloric acid $(\mathrm{HCl})$, ammonia $\left(\mathrm{NH}_{3}\right)$, total nitrogen (N-tot) and the chemical oxygen demand (COD), which comes from the energy production.

Characterisation factors are taken from Table 4 [18]. The reference units are the equivalent sulfur dioxide $\left(\mathrm{SO}_{2}\right)$ for acidification and the equivalent phosphatic compound $\left(\mathrm{PO}_{4}\right)$ for eutrophication.

Both of these impact categories are analysed in the following sections. 


\begin{tabular}{|c|c|c|}
\hline Emission & Acidification & Eutrophication \\
\hline \hline $\mathrm{NH}_{3}$ (ammonia) & 1.88 & 0.33 \\
\hline $\mathrm{HF}$ (fluorhydric acid) & 1.60 & -- \\
\hline $\mathrm{HCl}$ (hydrochloric acid) & 0.88 & -- \\
\hline $\mathrm{NO}_{2}$ or $\mathrm{NO}_{\mathrm{x}}$ (nitrogen oxides) & 0.70 & 0.13 \\
\hline $\mathrm{SO}_{2}$ or $\mathrm{SO}_{\mathrm{x}}$ (sulphur dioxide) & 1.00 & -- \\
\hline
\end{tabular}

TABLE 4. Characterisation factors used for acidification and eutrophication

\subsection{Acidification}

The results that correspond to this impact category (in reference units) for all the cements studied are shown in Table 5. This Table also shows the breakdown of the total emission into percentages by type of emission, so as to show the relative implication of each.

The main emissions of $\mathrm{SO}_{2}$ and $\mathrm{NO}_{\mathrm{x}}$ during the production of cement occur during the highenergy combustion of fossil fuels used to produce clinker and those used by mechanical equipment and vehicular transport. However $\mathrm{SO}_{2}$ emissions also occur when clays are used as raw materials in the production of clinker and the fraction of $\mathrm{SO}_{2}$ not chemically combined is emitted into the atmosphere.

The total emission (in $\mathrm{g}$ of equivalent $\mathrm{SO}_{2}$ per $\mathrm{kg}$ of cement) depends on the type of cement and ranges between 2 and 3 for Type I, between 1 and 2 for Type II, and has values lower than 1 for Types III and IV. These results are logical in the light of their high dependence on clinker content.

In Table 5, one can see the high proportion of total acidification that is typically caused by $\mathrm{NO}_{2}$ emissions (in $\mathrm{g}$ of equivalent $\mathrm{SO}_{2}$ ), which result from using fossil fuels in the clinker furnace, machinery and vehicles. The contributions of $\mathrm{HCl}$ and $\mathrm{NH}_{3}$ emissions, which are only included in some inventories, are practically negligible.

The inclusion of the latter two environmental interventions in some inventories and not in others can be due to the fact that they were only deemed to be significant in some of the studies, or because different criteria were used to define their system boundaries. This last possibility would be another example of the heterogeneity of existing inventories.

\subsection{Eutrophication}

Eutrophication is a consequence of, among other things, the emission of nitrogen oxides $\left(\mathrm{NO}_{\mathrm{x}}\right)$, which produces an enrichment of nutrients in aquatic reserves and agricultural soils. During the manufacture of clinker and cement, nitrogen oxides $\left(\mathrm{NO}_{\mathrm{x}}\right)$ are emitted, whose origin lies primarily in the type of fuel used in obtaining the clinker and in the production of electrical energy ([6]). There are other relevant emissions in the system being studied, such as ammonia $\left(\mathrm{NH}_{3}\right)$, total nitrogen (N-tot) and the chemical oxygen demand (COD).

Table 6 shows the results for the characterisation (in mg of equivalent $\mathrm{PO}_{4}$ per $\mathrm{kg}$ of cement) and the percentages that each emission represents in relation to the total. These results show that the principal source in this case is the emission of $\mathrm{NO}_{\mathrm{x}}$, and that other emissions are negligible.

The results in Table 6, as expected, depend on the type of cement and furthermore, on the type of clinker. Thus, for Type I cement, the results for the characterisation ranged from 250-350 mg of equivalent $\mathrm{PO}_{4}$, whilst for Type II, the range was $125-250$, and for Type III, 50 and 125.

The observed differences between some of the cements of similar Type are considered to be due to errors in the environmental interventions or in how the inventories defined their system boundaries, as stated in [6]. For example, in the case of Cement Portland I, which has a lower than average equivalent $\mathrm{PO}_{4} \quad(124.38 \mathrm{mg})$, mistakes were detected in its inventory, as mentioned before. Thus, the inventory probably omitted a considerable amount of the $\mathrm{NO}_{\mathrm{x}}$ emitted in the cradle to gate analysis of this cement.

These results suggest that a cement plant producing 1 million tonnes of cement a year releases $0.5 \mathrm{~kg}$ of phosphorus per hectare (assuming an influence distance of about $35 \mathrm{~km}$ - 20 miles - surrounding the cement plant), which is in line with the values set by the European Environment Agency [24] for the industrialised countries of Western Europe. 


\begin{tabular}{|c|c|c|c|c|c|c|}
\hline Type & Cements & $\mathrm{SO}_{2}$ & $\mathrm{NO}_{\mathrm{x}}$ & $\mathrm{HCl}$ & $\mathrm{NH}_{3}$ & Total \\
\hline \multirow{7}{*}{ I } & Cement Portland I & $\begin{array}{c}0.43 \\
(39 \%) \\
\end{array}$ & $\begin{array}{c}0.67 \\
(61 \%) \\
\end{array}$ & $\begin{array}{c}0.000019 \\
(0 \%)\end{array}$ & - & $\begin{array}{c}1.10 \\
(100 \%) \\
\end{array}$ \\
\hline & Cement $\mathrm{CH}$ & $\begin{array}{c}0.60 \\
(30 \%)\end{array}$ & $\begin{array}{c}1.40 \\
(70 \%)\end{array}$ & - & - & $\begin{array}{c}2.00 \\
(100 \%)\end{array}$ \\
\hline & Cement $\mathrm{N}$ & $\begin{array}{c}0.67 \\
(31 \%)\end{array}$ & $\begin{array}{c}1.46 \\
(69 \%)\end{array}$ & - & $\begin{array}{c}0.000010 \\
(0 \%)\end{array}$ & $\begin{array}{c}2.13 \\
(100 \%)\end{array}$ \\
\hline & Portlandcement NL1 & $\begin{array}{l}0.08 \\
(4 \%)\end{array}$ & $\begin{array}{c}1.81 \\
(96 \%)\end{array}$ & - & - & $\begin{array}{c}1.89 \\
(100 \%)\end{array}$ \\
\hline & Cement S & $\begin{array}{c}0.45 \\
(25 \%)\end{array}$ & $\begin{array}{c}1.36 \\
(75 \%)\end{array}$ & - & - & $\begin{array}{c}1.81 \\
(100 \%)\end{array}$ \\
\hline & Cement SF1 & $\begin{array}{c}0.63 \\
(20 \%)\end{array}$ & $\begin{array}{c}2.59 \\
(80 \%)\end{array}$ & - & - & $\begin{array}{c}3.22 \\
(100 \%)\end{array}$ \\
\hline & Cement SF2 & $\begin{array}{c}1.33 \\
(39 \%)\end{array}$ & $\begin{array}{c}2.07 \\
(61 \%)\end{array}$ & - & - & $\begin{array}{c}3.40 \\
(100 \%)\end{array}$ \\
\hline \multirow{4}{*}{ II } & Cement Portland* & $\begin{array}{c}1.16 \\
(35 \%) \\
\end{array}$ & $\begin{array}{c}2.17 \\
(65 \%)\end{array}$ & - & $\begin{array}{c}0.00036 \\
(0 \%)\end{array}$ & $\begin{array}{c}3.33 \\
(100 \%) \\
\end{array}$ \\
\hline & Portlandcement A & $\begin{array}{c}0.12 \\
(10 \%)\end{array}$ & $\begin{array}{c}1.10 \\
(90 \%) \\
\end{array}$ & - & - & $\begin{array}{c}1.22 \\
(100 \%) \\
\end{array}$ \\
\hline & Portlandcement NL2 & $\begin{array}{c}0.09 \\
(4 \%)\end{array}$ & $\begin{array}{c}2.07 \\
(96 \%)\end{array}$ & - & - & $\begin{array}{c}2.16 \\
(100 \%)\end{array}$ \\
\hline & Portlandcement NL3 & $\begin{array}{c}0.98 \\
(67 \%)\end{array}$ & $\begin{array}{c}0.49 \\
(33 \%)\end{array}$ & - & - & $\begin{array}{c}1.47 \\
(100 \%)\end{array}$ \\
\hline \multirow{4}{*}{ III } & Cement Hoogoven I & $\begin{array}{c}0.51 \\
(59 \%)\end{array}$ & $\begin{array}{c}0.35 \\
(41 \%)\end{array}$ & $\begin{array}{c}0.000015 \\
(0 \%)\end{array}$ & - & $\begin{array}{c}0.86 \\
(100 \%)\end{array}$ \\
\hline & Cement blast furnace slag* & $\begin{array}{c}0.58 \\
(43 \%)\end{array}$ & $\begin{array}{c}0.77 \\
(57 \%)\end{array}$ & & $\begin{array}{c}0.00076 \\
(0 \%)\end{array}$ & $\begin{array}{c}1.35 \\
(100 \%)\end{array}$ \\
\hline & Blastfurnace slag cement NL1 & $\begin{array}{c}0.03 \\
(5 \%) \\
\end{array}$ & $\begin{array}{c}0.60 \\
(95 \%) \\
\end{array}$ & - & - & $\begin{array}{c}0.63 \\
(100 \%) \\
\end{array}$ \\
\hline & Blastfurnace slag cement NL2 & $\begin{array}{c}0.43 \\
(61 \%)\end{array}$ & $\begin{array}{c}0.28 \\
(39 \%)\end{array}$ & - & - & $\begin{array}{c}0.71 \\
(100 \%)\end{array}$ \\
\hline IV & Cement Portlandash* & $\begin{array}{c}0.90 \\
(36 \%)\end{array}$ & $\begin{array}{c}1.63 \\
(64 \%)\end{array}$ & - & $\begin{array}{c}0.00025 \\
(0 \%)\end{array}$ & $\begin{array}{c}2.53 \\
(100 \%)\end{array}$ \\
\hline
\end{tabular}

* This inventory also states the presence of negligible amounts of fluorhydric acid (HF).

TABLE 5. Characterisation of the different types of cement in terms of the regional impact of acidification (in grams of equivalent $\mathrm{SO}_{2}$ per $\mathrm{kg}$ of cement)

\section{Local impact}

Dust in the air can cause respiratory problems in humans, livestock and wildlife. These effects are included in the impact category referred to as winter smog which is one consequence of particulate air pollution by $\mathrm{SO}_{2}$, dust and soot (the by-products of combustion).

Table 7 shows the results corresponding to this impact category for each of the cements studied. This shows the effects of individual emissions (in $\mathrm{g}$ of equivalent suspended particle matter SPM - per kg of cement) as well as the total effect. A characterisation factor 1 was adopted for all emissions.

The results of Table 7 show that soot has a negligible influence and that there is very high variation in the inventoried results for $\mathrm{SO}_{2}$ and dust. Again, this is most likely to be due to inconsistencies in the boundaries conditions used when compiling the inventories [6].

Considering absolute values, it should be noted that the values for Cement Portland I, Portlandcement NL1, Portlandcement NL3, Cement Hoogoven I and Blast furnace slag cement NL2 were two orders of magnitude higher than those of the other cements (0.25$1.50 \mathrm{~g}$ equivalent SPM per $\mathrm{kg}$ of cement). These results could be due to errors in the inventories, in which case further emphasis is placed on the need to standardise inventory methodology, or to the effect of some initial stages of the life cycle analysed (for instance energy production) or to the possibility that inappropriate dust filters were used at the production plant. The latter seems highly unlikely, due to the acute environmental sensitivity of the countries from which these cements came. 


\begin{tabular}{|c|c|c|c|c|c|c|}
\hline Type & Cements & $\mathrm{NO}_{\mathrm{x}}$ & $\mathrm{NH}_{3}$ & N-tot & COD & Total \\
\hline \multirow{7}{*}{ I } & Cement Portland I & $\begin{array}{c}124.38 \\
(100 \%)\end{array}$ & - & - & - & $\begin{array}{l}124.38 \\
(100 \%)\end{array}$ \\
\hline & Cement $\mathrm{CH}$ & $\begin{array}{l}260.00 \\
(100 \%)\end{array}$ & - & - & - & $\begin{array}{l}260.00 \\
(100 \%)\end{array}$ \\
\hline & Cement $\mathrm{N}$ & $\begin{array}{l}271.70 \\
(100 \%)\end{array}$ & $\begin{array}{l}0.002 \\
(0 \%)\end{array}$ & $\begin{array}{l}0.023 \\
(0 \%)\end{array}$ & - & $\begin{array}{l}271.70 \\
(100 \%)\end{array}$ \\
\hline & Portlandcement NL1 & $\begin{array}{c}335.40 \\
(100 \%)\end{array}$ & - & - & - & $\begin{array}{l}335.40 \\
(100 \%) \\
\end{array}$ \\
\hline & Cement S & $\begin{array}{l}252.20 \\
(100 \%)\end{array}$ & - & - & - & $\begin{array}{l}252.20 \\
(100 \%) \\
\end{array}$ \\
\hline & Cement SF1 & $\begin{array}{l}481.00 \\
(100 \%)\end{array}$ & - & $\begin{array}{l}0.029 \\
(0 \%)\end{array}$ & $\begin{array}{l}0.010 \\
(0 \%)\end{array}$ & $\begin{array}{l}481.04 \\
(100 \%)\end{array}$ \\
\hline & Cement SF2 & $\begin{array}{l}383.50 \\
(100 \%) \\
\end{array}$ & $\begin{array}{l}0.021 \\
(0 \%) \\
\end{array}$ & $\begin{array}{l}0.014 \\
(0 \%) \\
\end{array}$ & $\begin{array}{c}0.0049 \\
(0 \%)\end{array}$ & $\begin{array}{l}383.54 \\
(100 \%) \\
\end{array}$ \\
\hline \multirow{4}{*}{ II } & Cement Portland & $\begin{array}{l}403.01 \\
(100 \%) \\
\end{array}$ & $\begin{array}{l}0.060 \\
(0 \%) \\
\end{array}$ & - & - & $\begin{array}{l}403.07 \\
(100 \%) \\
\end{array}$ \\
\hline & Portlandcement A & $\begin{array}{c}204.10 \\
(100 \%)\end{array}$ & - & - & - & $\begin{array}{l}204.10 \\
(100 \%) \\
\end{array}$ \\
\hline & Portlandcement NL2 & $\begin{array}{l}383.50 \\
(100 \%)\end{array}$ & - & - & - & $\begin{array}{l}383.50 \\
(100 \%)\end{array}$ \\
\hline & Portlandcement NL3 & $\begin{array}{c}91.78 \\
(100 \%)\end{array}$ & - & - & - & $\begin{array}{c}91.78 \\
(100 \%)\end{array}$ \\
\hline \multirow{4}{*}{ III } & Cement Hoogoven I & $\begin{array}{c}65.86 \\
(100 \%) \\
\end{array}$ & - & - & - & $\begin{array}{c}65.86 \\
(100 \%) \\
\end{array}$ \\
\hline & Cement blast furnace slag & $\begin{array}{c}142.48 \\
(100 \%)\end{array}$ & $\begin{array}{c}0.13 \\
(0 \%) \\
\end{array}$ & - & - & $\begin{array}{l}142.61 \\
(100 \%)\end{array}$ \\
\hline & Blastfurnace slag cement NL1 & $\begin{array}{l}110.50 \\
(100 \%)\end{array}$ & - & - & - & $\begin{array}{r}110.50 \\
(100 \%)\end{array}$ \\
\hline & Blastfurnace slag cement NL2 & $\begin{array}{c}51.87 \\
(100 \%) \\
\end{array}$ & - & - & - & $\begin{array}{c}51.87 \\
(100 \%) \\
\end{array}$ \\
\hline IV & Cement Portlandash & $\begin{array}{l}302.38 \\
(100 \%)\end{array}$ & $\begin{array}{l}0.040 \\
(0 \%)\end{array}$ & - & - & $\begin{array}{c}302.42 \\
(100 \%)\end{array}$ \\
\hline
\end{tabular}

TABLE 6. Characterisation of the different types of cement in terms of the regional effect of eutrophication (in milligrams of equivalent $\mathrm{PO}_{4}$ per $\mathrm{kg}$ of cement)

\section{Other characterised environmental} impacts stemming from minor emissions

The results shown in [6] demonstrate the existence of other emissions that, though of lesser magnitude, may have a significant impact on some impact categories. This section examines some of these that have both regional implications, such as the photochemical ozone formation (summer smog), and local implications, such as heavy metals or carcinogens. These have been characterised using the factors in Table 8 .

It is important to note that these emissions stem mainly from energy-producing processes, in particular electricity production and the refining of primary fuels (petroleum, coal, etc.). These, despite the environmental effects that they entail within the system boundaries of cement manufacture (cradle to gate), generally affect areas that are not local to the cement plant.
The reference units for these impact categories are equivalent ethylene $\left(\mathrm{C}_{2} \mathrm{H}_{4}\right)$ for the photochemical ozone formation (summer smog), equivalent benzo(a)pyrene (B(a)P) for carcinogens and equivalent lead $(\mathrm{Pb})$ for heavy metals.

\subsection{Photochemical ozone formation}

The photochemical ozone formation (summer smog) depends on the presence in the troposphere of oxidizing photochemical substances, such as volatile organic compounds (VOCs) and carbon monoxide (CO). The effect of solar radiation on these substances gives rise to reactions between the oxidizing photochemical compounds and hydroxyl radicals $\left(\mathrm{OH}^{-}\right)$, in presence of $\mathrm{NO}_{\mathrm{x}}$, resulting in the formation of tropospheric ozone $\left(\mathrm{O}_{3}\right)$. 


\begin{tabular}{|c|c|c|c|c|c|}
\hline Type & Cements & Dust & $\mathrm{SO}_{2}$ & Soot & Total \\
\hline \multirow{7}{*}{ I } & Cement Portland I & $\begin{array}{l}10.00 \\
(96 \%)\end{array}$ & $\begin{array}{c}0.43 \\
(4 \%) \\
\end{array}$ & $\begin{array}{c}0.0092 \\
(0 \%)\end{array}$ & $\begin{array}{c}10.43 \\
(100 \%)\end{array}$ \\
\hline & Cement $\mathrm{CH}$ & $\begin{array}{c}0.30 \\
(33 \%)\end{array}$ & $\begin{array}{c}0.60 \\
(67 \%)\end{array}$ & $x_{2}$ & $\begin{array}{c}0.90 \\
(100 \%) \\
\end{array}$ \\
\hline & Cement $\mathrm{N}$ & $\begin{array}{c}0.18 \\
(21 \%)\end{array}$ & $\begin{array}{c}0.67 \\
(79 \%)\end{array}$ & - & $\begin{array}{c}0.85 \\
(100 \%)\end{array}$ \\
\hline & Portlandcement NL1 & $\begin{array}{c}7.50 \\
(99 \%)\end{array}$ & $\begin{array}{c}0.08 \\
(1 \%)\end{array}$ & - & $\begin{array}{c}7.58 \\
(100 \%) \\
\end{array}$ \\
\hline & Cement S & $\begin{array}{c}0.16 \\
(26 \%)\end{array}$ & $\begin{array}{c}0.45 \\
(74 \%)\end{array}$ & - & $\begin{array}{c}0.61 \\
(100 \%)\end{array}$ \\
\hline & Cement SF1 & $\begin{array}{c}0.39 \\
(38 \%) \\
\end{array}$ & $\begin{array}{c}0.63 \\
(62 \%) \\
\end{array}$ & - & $\begin{array}{c}1.02 \\
(100 \%) \\
\end{array}$ \\
\hline & Cement SF2 & $\begin{array}{c}0.33 \\
(20 \%)\end{array}$ & $\begin{array}{c}1.33 \\
(80 \%)\end{array}$ & - & $\begin{array}{c}1.66 \\
(100 \%) \\
\end{array}$ \\
\hline \multirow{4}{*}{ II } & Cement Portland & $\begin{array}{c}0.24 \\
(17 \%) \\
\end{array}$ & $\begin{array}{c}1.16 \\
(83 \%) \\
\end{array}$ & - & $\begin{array}{c}1.40 \\
(100 \%)\end{array}$ \\
\hline & Portlandcement A & $\begin{array}{c}0.17 \\
(59 \%)\end{array}$ & $\begin{array}{c}0.12 \\
(41 \%)\end{array}$ & - & $\begin{array}{c}0.29 \\
(100 \%) \\
\end{array}$ \\
\hline & Portlandcement NL2 & $\begin{array}{c}0.19 \\
(68 \%)\end{array}$ & $\begin{array}{l}0.091 \\
(32 \%)\end{array}$ & - & $\begin{array}{c}0.28 \\
(100 \%)\end{array}$ \\
\hline & Portlandcement NL3 & $\begin{array}{l}79.60 \\
(99 \%)\end{array}$ & $\begin{array}{c}0.97 \\
(1 \%)\end{array}$ & - & $\begin{array}{c}80.57 \\
(100 \%) \\
\end{array}$ \\
\hline \multirow{4}{*}{ III } & Cement Hoogoven I & $\begin{array}{l}10.00 \\
(95 \%)\end{array}$ & $\begin{array}{c}0.51 \\
(5 \%) \\
\end{array}$ & $\begin{array}{l}0.010 \\
(0 \%)\end{array}$ & $\begin{array}{c}10.52 \\
(100 \%)\end{array}$ \\
\hline & Cement blast furnace slag & $\begin{array}{c}0.084 \\
(13 \%)\end{array}$ & $\begin{array}{c}0.58 \\
(87 \%)\end{array}$ & - & $\begin{array}{c}0.66 \\
(100 \%) \\
\end{array}$ \\
\hline & Blastfurnace slag cement NL1 & $\begin{array}{c}0.14 \\
(82 \%)\end{array}$ & $\begin{array}{c}0.031 \\
(18 \%)\end{array}$ & - & $\begin{array}{c}0.17 \\
(100 \%)\end{array}$ \\
\hline & Blastfurnace slag cement NL2 & $\begin{array}{c}88.60 \\
(99.5 \%) \\
\end{array}$ & $\begin{array}{c}0.43 \\
(0.5 \%) \\
\end{array}$ & - & $\begin{array}{c}89.03 \\
(100 \%) \\
\end{array}$ \\
\hline IV & Cement Portlandash & $\begin{array}{c}0.18 \\
(17 \%) \\
\end{array}$ & $\begin{array}{c}0.90 \\
(83 \%)\end{array}$ & - & $\begin{array}{c}1.08 \\
(100 \%) \\
\end{array}$ \\
\hline
\end{tabular}

TABLE 7. Characterisation of the different types of cement in terms of the local impact of winter smog (in $\mathrm{g}$ of equivalent SPM per $\mathrm{kg}$ of cement)

Table 9 shows the results of these impacts, measured in mg of equivalent $\mathrm{C}_{2} \mathrm{H}_{4}$ per $\mathrm{kg}$ of cement. The results are highly scattered, and correlation with the cement type or definition of representative values is impossible. This fact can again be attributed, at least in part, to the criteria utilised or to the definition of the system boundaries in each case. However, it could also depend, in a decisive way, on the fuels utilised in the manufacture of clinker, some of which may lead to these sorts of emissions

It can be seen in Table 9 that there are cements whose inventories do not include the information corresponding to ozone formation (summer smog), which again calls into question the rigour with which some of the existing inventories were designed. Furthermore, Cement SF1 (367 mg of equivalent $\mathrm{C}_{2} \mathrm{H}_{4}$ per kg of cement) and Cement blast furnace slag (364 $\mathrm{mg}$ of equivalent $\mathrm{C}_{2} \mathrm{H}_{4}$ per $\mathrm{kg}$ of cement) have values an order of magnitude higher than the rest and it is impossible to define representative values for the cements studied. The best explanation for the degree of variation shown is that the results considered in Table 9 are highly dependent on the energy sources of the system and additional information on the processes that supplied power to the cement production system is needed. 


\begin{tabular}{|l|c|c|c|}
\hline Emission & Ozone formation & Heavy metals & Carcinogens \\
\hline \hline Aldehydes & 0.443 & -- & -- \\
\hline Arsenic & -- & -- & 0.044 \\
\hline Benzene & 0.189 & -- & 0.00044 \\
\hline Benzo(a)pyrene & -- & -- & 1.0 \\
\hline $\mathrm{Cd}$ (cadmium) & -- & 50 & -- \\
\hline $\mathrm{Cr}$ (chromium) & -- & 0.2 & -- \\
\hline $\mathrm{CH}_{4}$ (methane) & 0.007 & -- & -- \\
\hline $\mathrm{C}_{\mathrm{x}} \mathrm{H}_{\mathrm{y}}$ & 0.398 & -- & -- \\
\hline Ethylbenzene & & -- & -- \\
\hline Phenol & & 0.761 & -- \\
\hline Fluoroethane & & -- & -- \\
\hline $\mathrm{Hg}$ & & -- & 1.0 \\
\hline $\mathrm{Ni}$ & & -- & -- \\
\hline PAHs & & 0.761 & -- \\
\hline $\mathrm{Pb}$ & & -- & 1.0 \\
\hline VOC & & 0.398 & -- \\
\hline
\end{tabular}

TABLE 8. Characterisation factors for other emissions that affect the impact categories of photochemical ozone formation, heavy metals and carcinogens.

\subsection{Heavy metals and carcinogens}

Any metal whose specific weight is higher than that of titanium $\left(4.51 \mathrm{gr} / \mathrm{cm}^{3}\right)$ is considered to be a heavy metal. These are found in small quantities in raw materials such as crude oil, rock and coal. As not all the heavy metals necessarily have adverse effects on health and not all of the harmful ones have the same implications, one must use characterisation factors to analyse their effect (Table 8).

Based on the inventories used, it is suggested that these emissions originate from the energyproducing systems, as there is no evidence that they are included in the raw materials used to make cement. The highly scattered results (very different orders of magnitude) make it impossible to assign a representative value to the cement (independent of its type), since such a value depends on the type of fuels utilised, both in the energy production and in the clinker furnace.

The results for Cement $\mathrm{CH}$ (4.01 $\mathrm{mg}$ of equivalent $\mathrm{Pb}$ per kg of cement) are surprisingly high. This result is either an undetected error inherent to the inventory, or the consequence of using fuels with extremely high contents in heavy metals.

As for the carcinogens, the same general comments can be made as for the heavy metals in terms of the origin of the emissions. As these results are significantly scattered and vary by orders of magnitude it is impossible to define representative values.

\section{Conclusions}

The characterisation of the environmental impact of manufacturing $1 \mathrm{~kg}$ of a variety of cements, undertaken according to the LCA methodology, have led to the following conclusions:

- The errors and ambiguities of system boundaries as described in Reference [6] have again been observed. This is logical, as characterisation is a phase that takes place after an inventory is made, and which works from the environmental interventions stated in the latter. Consequently, inventories should be defined consistently, and their system boundaries must be adequately defined, structured and described.

- The contribution of carbon dioxide $\left(\mathrm{CO}_{2}\right)$ to the greenhouse effect ranges between 98.8 and $100 \%$ of the total - it is the main cause. The influences of other gases (methane, $\mathrm{CH}_{4}$ or nitrous oxide, $\mathrm{N}_{2} \mathrm{O}$ ), are much smaller. Quantitatively, $\mathrm{CO}_{2}$ emissions are significant and range in the order of $800 \mathrm{~g}$ of $\mathrm{CO}_{2}$ in the production of $1 \mathrm{~kg}$ of Type I cement. 


\begin{tabular}{|c|c|c|c|c|}
\hline \multirow[b]{2}{*}{ Type } & \multirow[b]{2}{*}{ Cements } & \multirow{2}{*}{$\begin{array}{c}\text { Regional } \\
\text { Formation of ozone } \\
\text { (mg equiv. } \mathrm{C}_{2} \mathrm{H}_{4} \text { ) }\end{array}$} & \multicolumn{2}{|c|}{ Local } \\
\hline & & & $\begin{array}{c}\text { Carcinogens } \\
\text { (mg equiv. } \mathrm{B}(\mathrm{a}) \mathrm{P})\end{array}$ & $\begin{array}{l}\text { Heavy metals } \\
\text { (mg equiv. } \mathrm{Pb} \text { ) }\end{array}$ \\
\hline \multirow{7}{*}{ I } & Cement Portland I & 14.90 & 0.000021 & 0.0058 \\
\hline & Cement CH & - & 0.0011 & 4.01 \\
\hline & Cement N & 53.50 & 0.00034 & 0.53 \\
\hline & Portlandcement NL1 & 1.19 & - & - \\
\hline & Cement S & 53.50 & 0.00034 & 0.53 \\
\hline & Cement SF1 & 367.00 & 0.0046 & 0.11 \\
\hline & Cement SF2 & 6.33 & 0.0014 & 0.38 \\
\hline \multirow{4}{*}{ II } & Cement Portland & 174.00 & - & - \\
\hline & Portlandcement A & 95.50 & 0.00015 & 0.12 \\
\hline & Portlandcement NL2 & - & - & 0.013 \\
\hline & Portlandcement NL3 & 8.68 & - & - \\
\hline \multirow{4}{*}{ III } & Cement Hoogoven I & 12.70 & 0.000022 & 0.0059 \\
\hline & Cement blast furnace slag & 363.00 & - & - \\
\hline & Blastfurnace slag cement NL1 & - & - & 0.013 \\
\hline & Blastfurnace slag cement NL2 & 3.74 & - & - \\
\hline IV & Cement Portlandash & 182.00 & - & - \\
\hline
\end{tabular}

TABLE 9. Characterisation of the different types of cement in terms of other categories of environmental impact considered.

- Acidification is mainly caused by $\mathrm{SO}_{2}$ and $\mathrm{NO}_{\mathrm{x}}$ emissions. The total acidification (in $\mathrm{g}$ of equivalent $\mathrm{SO}_{2}$ ) depends on the type of cement (its content in clinker). These values range from 2-3 (Type I), 1-2 (Type II) and $<1$ (Types III and IV). $\mathrm{NO}_{\mathrm{x}}$ emissions are the prime source of acidification, while the effect of $\mathrm{HCl}$ and $\mathrm{NH}_{3}$ is practically negligible.

- The main cause of eutrophication is the emission of $\mathrm{NO}_{\mathrm{x}}$. The remainder of the emissions had a negligible effect on this environmental impact. The results for Type I was $250-350 \mathrm{mg}$ of equivalent $\mathrm{PO}_{4}$, whereas for Type II the values were 125-250 and for Type III, 50-125. These results mean that a cement plant that produces 1 million tonnes a year also produces a phosphorus load of approximately $0.5 \mathrm{~kg}$ per hectare (assuming an influence distance of about $35 \mathrm{~km}-20$ miles - surrounding the cement plant).

- For winter smog (small dust particles in suspension in the air), the main sources are $\mathrm{SO}_{2}$, dust and soot. The results show that emissions of soot have a negligible effect and that there is a great disparity in the inventoried influences of $\mathrm{SO}_{2}$ and dust (in percentage terms).

- In the cases of photochemical ozone formation (summer smog), heavy metals and carcinogens, the results are highly variable and depend on the fuels and raw materials used. In most cases, emissions stem in the main from energy-producing processes and in particular the production of electricity and the refining of primary fuels (crude oil, coal, etc.). Thus, despite the environmental loads that are implied within the boundaries of the system of cement production, the processes correspond to zones that are likely not to be local to the cement plants themselves.

\section{Acknowledgements}

The authors wish to acknowledge the aid they received through a number of projects funded by public (CICYT, Interministerial Science and Technology Commission) and private (IECA) bodies.

\section{References}

[1] International Organisation for Standardisation, ISO 14040, Environmental management - Life cycle assessment Principles and framework, Geneva, 1997.

[2] Cement and Concrete Association of Australia, The Sydney House - Life Cycle Assessment - Report, 2001.

[3] International Organisation for Standardisation, ISO 14041, Environmental management - Life cycle assessment - Goal and scope definition and inventory analysis, Geneva, 1998. 
[4] The Nordic Council of Ministers, Product Life Cycle Assessment - Principles and Methodology, Copenhagen, Nord 1992:9.

[5] Wrisberg, N. (coordinator), Definition Document, LCANET Board, Leiden, 1996.

[6] A. Josa, A. Aguado, A. Heino, E. Byars and A. Cardim, Comparative analysis of available life cycle inventories of cement in the EU, paper accepted for publication in Cement and Concrete Research.

[7] Pré Consultants bv, SimaPro software, v. 4.0, Amesfoort, 1997.

[8] Intron, An Overview of Available LCI Data: Cement, Concrete and other Building Materials, Intron report No. 97079, Sittard, 1997.

[9] Swiss Federal Institute of Technology, Environmental Life-Cycle Inventories of Energy Systems - An Environmental Database for the Accounting of Energy Inputs in Product Life Cycle Assessment and the Comparative Assessment of Energy Systems, Institute of Energy Technology, Zurich, July 1994.

[10] H. Lundström, G. Ölund and T. Rydberg, Life Cycle Assessment of a Concrete Sewage Pipe, CIT ecologic, Chalmers Industriteknik, 1996.

[11] F. Hoefnagels and V. de Lange, De milieubelasting van houten en betonnen dwarsliggers, Consultancy and Research for Environmental Management, Amsterdam, February 1993.

[12] Chalmers University of Technology, LCA of building frame structures, environmental impact over the life cycle of concrete and steel frames, October 1996.

[13] T. Häkkinen, and K. Mäkelä, Environmental adaption of concrete Environmental impact of concrete and asphalt Pavements, Technical Research Centre of Finland, Espoo, 1996.

[14] M. Vold, and A. Ronning, LCA of cement and concrete, Stiftelsen Østfoldforskning, Fredrikstad, November 1995.

[15] H. M. Knoflacher, P. Tuschi and A. Medwedeff, Die ökologische Standortbestimmung des in österreichischen werken hergestellten Bindemittels zement, Vienna, June 1995.

[16] A. Schuurmans, Milieumatenconcept voor de bouw deterministische uitwerking proefproject weg, Intron-report 93278, November 1994.

[17] P. Fraanje, H. Jannink, V. de Lange and R. Lim, Milieubelasting van twee aanbruggen pilot study, Interfacultaire Vakgroep Milieukunde Universiteit van Amsterdam, Amsterdam, May 1992.

[18] R. Heijungs, J.B. Guinée, G. Huppes, R.M. Lankreijer, H.A. Udo de Haes, A. Wegener Sleewijk, A.M.M. Ansems, P.G. Engels, R. van
Duin, H.P. de Goede, Environmental life cycle assessment of products - Guide and backgrounds, Centre of Environmental Science, Leiden University (CML), Leiden, The Netherlands, 1992.

[19] M. Goedkoop and R. Spriensma, The Ecoindicator 99 - A damage oriented method for Life Cycle Impact Assessment - Methodology report, Pré Consultants, Amersfoort, The Netherlands, 1999.

[20] H. Wenzel, M. Hauschild and L. Alting, Environmental Assessment of Products, volume 1: Methodology, tools and case studies in product development, volume 2: Scientific background, Chapman \& Hall, 1997.

[21] J.B. Guinée, M. Gorrée, R. Heijungs, G. Huppes, R. Kleijn, A. Wegener Sleeswijk, H.A. Udo de Haes, J.A. de Bruijn, and R. van Duin, Life cycle assessment: an operational guide to the ISO standards, volume 1: LCA in perspective, volume 2: Guide, volume 3: Scientific backgrounds, Centre of Environmental Science, Leiden University (CML), Leiden, The Netherlands, 2000.

[22] J.T. Houghton, L.G. Meira Filho, B. Lim, K. Treanton, I. Mamaty, Y. Bonduki, D.J. Griggs B.A. and Callender, Revised 1996 IPCC Guidelines for National Greenhouse Gas Inventories - Reporting instructions, volume 1, IPCC/OECD/IEA, Intergovernmental Panel on Climate Change, UK Meteorological Office, Bracknell, UK.

[23] Cembureau, World Cement Directory, Brussels, 2002.

[24] European Environmental Agency, Environmental signal 2000 - Regular indicator, Copenhagen, 2000. 